\title{
Financing of Infrastructure Projects as a Dominant of Banks' Credit-Investment Activity with State's Capital Participation
}

\author{
Anatolii Drobiazko ${ }^{1 *}$ [0000-0002-0453-0709], Dominique Menu 2 [0000-0001-6973-8466] \\ ${ }^{1}$ Academy of Financial Management, Kiev, Ukraine \\ ${ }^{2}$ Corporate and Investment Banking, Paris, France \\ *adrobyazko@ukr.net
}

\begin{abstract}
The COVID-19 pandemic crisis has negatively affected Ukraine's economic development, with GDP declining by 4.0\% in 2020. Despite the fact that banking sector has ensured the stability of settlement system and has not deepened the crisis, as it was in previous years, there is a need to intensify lending activity and increase the banks' role in supporting economic processes. A number of previous crises have led to the accumulation in banks 'balance sheets of significant amounts of negatively classified assets (NPLs), which constrain banks' participation in overcoming current problems. The article considers the banks' role with state's participation in the process of intensifying credit support to the economy. One of the key areas of development is the creation of a national bank for reconstruction and development to support long-term strategic government programs by reorienting one of the existing state-owned banks for these purposes.
\end{abstract}

Keywords: banks, state banks, banking sector, economic growth, development bank, public sector.

\section{INTRODUCTION}

Banks with state participation in capital (BSCP) in Eastern Europe occupy a prominent place in national banking systems. As a rule, in the countries that are Ukraine's western neighbors, BSCP are specialized and their mission is aimed mainly at long-term development programs and support of export-import operations. In Ukraine, the four largest banks are owned by the state, but there is no specialized development bank among them, and the domestic export-import bank implements an universal business model, which includes customer service and corporate clients, as well as the function of "a bank for banks". As a rule, in Eastern European countries BSCP implements mainly the following types of national strategic programs: infrastructure development, support for small and medium-sized businesses, regional development, elimination of sectoral disparities. These programs are divided by products into loans, guarantees and subsidies. In some countries, BSCP also implements programs of student loans, mortgage lending, support for innovative and start-up enterprises with grants. [1]

After the declaration of independence during the collapse of the Soviet Union, Ukraine as an independent country began to create all national institutions, including the banking system, almost started with a clean slate. The National Bank of Ukraine (the first level of the banking system) and commercial banks (the second level of the banking system) created in that period began to serve the economy needs in a deep economic crisis, transforming along with the socio- economic change of the state. The peculiarity of the development of the second-tier banking sector in Ukraine was that it developed mainly due to private investment in high competition between two hundred legal entities. The share of two state-owned banks (UkrEximBank and OschadBank) in the first decade of development in banking assets did not exceed $10 \%$. After the Orange Revolution, Ukraine opened up to foreign capital in 2005. This was due to the structures of the banking and insurance markets. The share of banks with $100 \%$ of foreign capital in a short period exceeded $35 \%$ of the total system capitalization. But the development of the banking system was not linear. Ukraine has gone through a series of economic crises for thirty years: in 1998-1999 the "Russian tsunami" defaulted on the largest foreign economic partner at the time. There was the "global financial crisis" in 2008 2009 , which led to a deep devaluation and destabilization 
of the mortgage market with a high share of foreign currency loans in this sector. The crisis of 2014-2015 is the beginning of Russian military aggression with the annexation of Crimea and certain areas of Donbass, where Ukraine lost not only territory but also almost $20 \%$ of industry, which generated export revenue, and banks received significant amounts of NPL under objective circumstances. In each of these crises, the state has invested financial resources to support the banking sector, including through the nationalization of bankrupt banks, resulting in 2021 as control of the four largest banks, which control almost $54 \%$ of the net assets of the banking system.

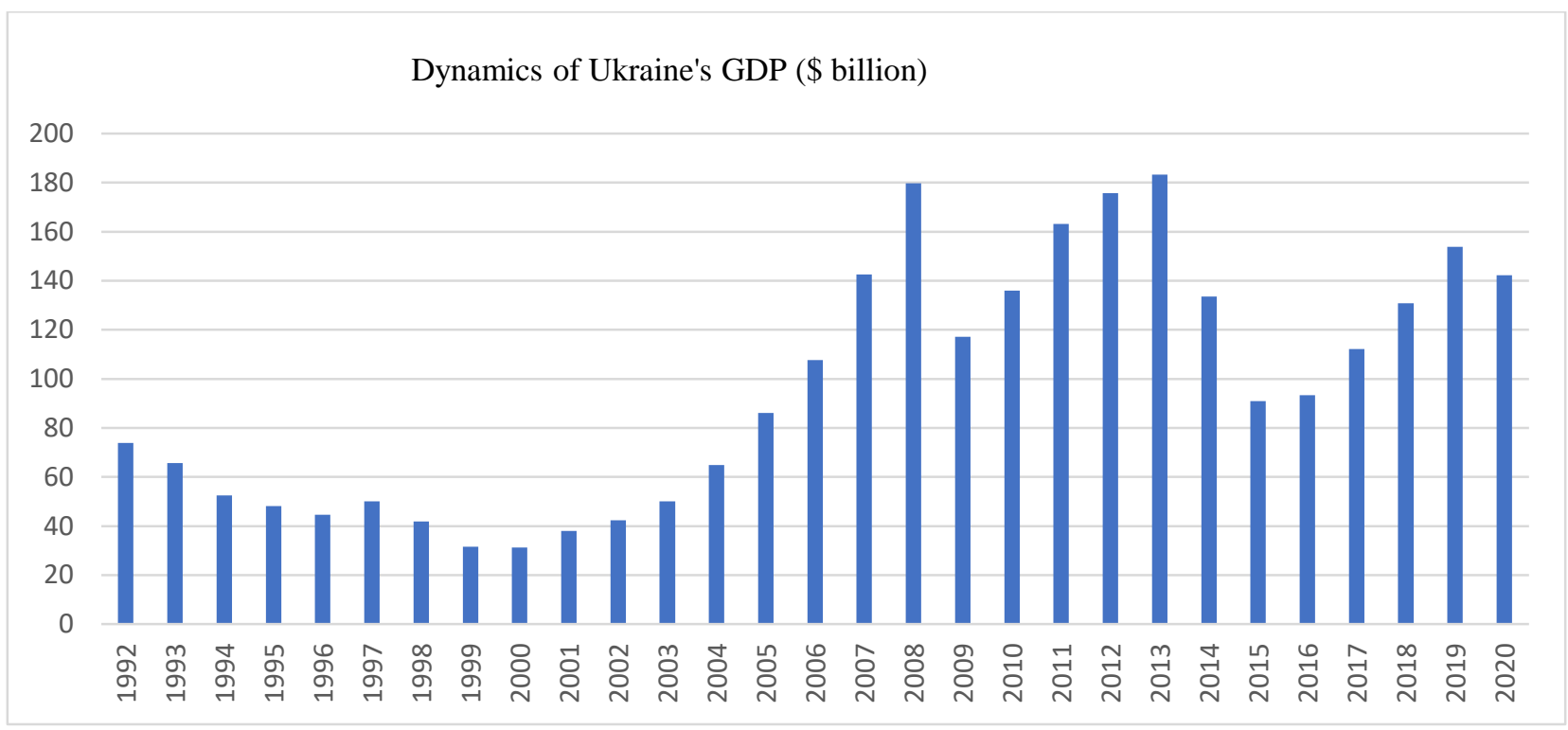

Source: World Development Indicators

The COVID-19 pandemic and the ensuing crisis are making significant adjustments to the management practices of the economy in all chains, including banking and monetary [2] policy. One of the significant problems is that the economy is becoming a "hostage" of medicine and must find a solution in an atypical situation, the final development of which is difficult to predict [3-6]. The current solutions proposed by the governments of different countries are still aimed at mitigating the crisis, rather than overcoming it completely, especially in conditions where it is impossible to guarantee the recurrence of such an atypical crisis due to the emergence of a new strain or virus. Therefore, the issue of the influence of state-owned banks on economic development is important for economic research.

The aim of the paper is to substantiate the development in Ukraine of an effective mechanism for the operation of state-owned banks as drivers of innovative economic development, taking into account international experience.

\section{RESULTS OF THE RESEARCH}

It is worth outlining the preconditions of the current situation. Ukraine became a member of the IMF in 1992. In the mid-90s of the twentieth century an international commitment was made to ensure the convertibility of the hryvnia in current trade transactions. It was not always possible to put it into practice in full, as "manual" financial flows were managed, primarily to service the so-called critical imports: the country was and is dependent on the supply of gas, oil, coal and nuclear fuel for nuclear power plants [7]. It is considered the studies, comparing the level of monetization of Ukraine in 2020 after a number of crises and countries - western neighbors, which are members of the EUR, but have their own currency [8]. Assessment of the monetization of the economy, the ratio of money supply to GDP, as well as a comparison of the money supply in circulation showed a significant lag of Ukraine from neighboring countries in terms of monetization. The monetization of the economy in dollar equivalent in our country is twice lower than in Hungary $(2,3)$ and Romania $(2,0)$, four times - than in the Czech Republic $(4,3)$, and 8,4 times - than in Poland. The volume of customer money in the banking system in Ukraine is 5.3 times lower than in the Czech Republic and 9.3 times lower in Poland. As of 2020, the assets of the national banking system (gross) of Ukraine, even excluding their non-functioning part, are twice smaller than in Poland and Hungary, and almost three times smaller than in the Czech Republic.

The main problem that prevents the national tier two banking system from lending to the economy in 2021 is the high share of negatively classified assets (NPLs) that has accumulated in banks' balance sheets. Implementing the Basel Principles into the legislative and regulatory framework, the banking system of Ukraine has faced a number of limitations that negatively affect the efficiency 
of transmission mechanism of redistribution of resources generated by the National Bank of Ukraine.

Despite the fact that for the period from January 2019 to July 2021 the share of negatively classified assets decreased from $52.9 \%$ to $37.2 \%$, and the state of NPL banks with state participation decreased from $67.9 \%$ to
$54.6 \%$, the quality of the banking system's assets does not give hope that the banking system will provide the necessary support in overcoming the COVID-19 pandemic' effects in 2021 (Table 1). Table 2 gives the comparison of the asset quality of the largest banks with state, foreign, including Russian and private Ukrainian capital as of July 1, 2021.

Table 1. The share of negatively classified loans in the banking system as of 01.07.2021 (UAH billion)

\begin{tabular}{|c|c|c|c|c|c|c|c|c|c|}
\hline \multirow{3}{*}{ Indicator } & \multicolumn{3}{|c|}{ Business entities } & \multicolumn{3}{|c|}{ Private customers } & \multicolumn{3}{|c|}{$\begin{array}{c}\text { Total, incl. IBC and } \\
\text { Budget }\end{array}$} \\
\hline & \multicolumn{2}{|c|}{$\Sigma$ credits } & \multirow{2}{*}{$\begin{array}{l}\text { NPL, } \\
\%\end{array}$} & \multicolumn{2}{|c|}{$\Sigma$ credits } & \multirow{2}{*}{$\begin{array}{l}\text { NPL, } \\
\%\end{array}$} & \multicolumn{2}{|c|}{$\Sigma$ credits } & \multirow{2}{*}{ NPL, } \\
\hline & $\begin{array}{c}\text { All } \\
\text { classes }\end{array}$ & $\begin{array}{l}\text { Q, J } \\
\text { classc }\end{array}$ & & $\begin{array}{c}\text { All } \\
\text { classes }\end{array}$ & $Q$ class & & $\begin{array}{c}\text { All } \\
\text { classes }\end{array}$ & $\mathbf{Q}, \mathbf{L}, \mathbf{J}$ & \\
\hline Total & 809,4 & 353,4 & 43,7 & 229,1 & 51,3 & 22,4 & 1090,6 & 405,5 & 37,2 \\
\hline with state share & 427,4 & 276,2 & 64,6 & 85,8 & 18,5 & 21,6 & 541,5 & 295,5 & 54,6 \\
\hline $\begin{array}{l}\text { JSC CB } \\
\text { "PRIVATBANK" }\end{array}$ & 178,3 & 166,0 & 93,1 & 62,7 & 11,5 & 18,3 & 248,7 & 177,4 & 71,3 \\
\hline $\begin{array}{l}\text { with private } \\
\text { capital }\end{array}$ & 125,4 & 13,2 & 10,5 & 61,5 & 9,3 & 15,1 & 188,1 & 22,5 & 12,0 \\
\hline $\begin{array}{l}\text { foreign banking } \\
\text { groups }\end{array}$ & 256,6 & 64,0 & 24,9 & 81,8 & 23,5 & 28,8 & 361,1 & 87,5 & 24,2 \\
\hline $\begin{array}{l}\text { Banks of the } \\
\text { Russian } \\
\text { Federation }\end{array}$ & 63,0 & 56,7 & 89,9 & 2,2 & 2,1 & 98,5 & 65,2 & 58,8 & 90,2 \\
\hline
\end{tabular}

Source: Official website of the NBU, www.bank.gov.ua.

The COVID-19 crisis, brought into the economy from outside, has a direct impact on the banking sector. On the one hand, the government would like to stimulate economic processes with cheap credit resources. On the other hand, banks are wary of "zombie borrowers" who may not withstand an unpredictable crisis in time and scale. The instrument of state guarantees in lending to government programs transfers the risks [9] of future losses to budget expenditures. There is a balance in the banking market in 2021: on the one hand, activity is insufficient to stimulate significant economic development, but, on the other hand, the system does not slide to significant shocks when the financial sector in 2008 and 2015 generated crises for the economy. The prudent policy of banks in lending to individuals can be explained by the regulator decision, according to which, during the COVID-19 crisis, customers have the opportunity to take deferrals for debt service, which does not stimulate banking activity.

In 2020, in the conditions of the COVID-19 pandemic crisis, the banking system of Ukraine ensured the stability of settlements in the national economy. Despite the unfavorable conditions of 2020-2001 and the crisis in the economy, the banking system withstood the blow, did not generate a deepening crisis, as in previous periods, and has a margin of liquidity to resume lending to the real sector [10]. In 2020, while fulfilling Ukraine's commitments to the IMF to streamline negatively classified assets in banks 'balance sheets, state-owned banks reduced lending to the corporate sector of the economy. Private banks and banks of foreign groups wrote off NPL assets a few years earlier, so their balance sheets looked better.

Therefore, the question arises how to solve the accumulated problems. Under government programs in 2020 and 2021, preferential lending systems "affordable loans of 5-7-9\% to support business "were launched with the involvement of budgetary resources. Also, opportunities have been expanded to provide government guarantees on loans and interest rate subsidies. Unfortunately, the analysis of development strategies of all four state-owned banks shows that the role of the national development bank is not assigned to any of them. On what it would be expedient to reorient one of the state banks in the current conditions. It is clear that this institution must undergo the rehabilitation of assets, transform the resource base to be able to enter the domestic and foreign borrowing markets for these purposes. The transformation of the public banking sector in Ukraine should take place in parallel with the approval by the Government of Ukraine of national and regional credit incentive programs for the economy. 
Table 2. The share of negatively classified loans in the largest banks with capital (public, foreign, private) data of 01.07.2021 (billion UAH)

\begin{tabular}{|c|c|c|c|c|c|c|c|c|c|}
\hline \multirow{3}{*}{ Banks } & \multicolumn{3}{|c|}{ Business entities } & \multicolumn{3}{|c|}{ Private customers } & \multicolumn{3}{|c|}{$\begin{array}{l}\text { Total, incl. IBC and } \\
\text { Budget }\end{array}$} \\
\hline & \multicolumn{2}{|c|}{$\Sigma$ credits } & \multirow{2}{*}{$\begin{array}{c}\text { NPL, } \\
\%\end{array}$} & \multicolumn{2}{|c|}{$\Sigma$ credits } & \multirow{2}{*}{$\begin{array}{c}\text { NPL, } \\
\%\end{array}$} & \multicolumn{2}{|c|}{$\Sigma$ credits } & \multirow{2}{*}{$\begin{array}{l}\text { NPL } \\
\%\end{array}$} \\
\hline & $\begin{array}{c}\text { All } \\
\text { classes }\end{array}$ & $\begin{array}{l}\mathbf{Q}, \mathbf{J} \\
\text { class }\end{array}$ & & $\begin{array}{c}\text { All } \\
\text { classes }\end{array}$ & $\begin{array}{c}\mathbf{Q} \\
\text { class }\end{array}$ & & $\begin{array}{c}\text { All } \\
\text { classes }\end{array}$ & $\begin{array}{c}\mathbf{Q}, \mathbf{L}, \\
\mathbf{J}\end{array}$ & \\
\hline CB "UkrEximBank" & 101,4 & 55,7 & 54,9 & 1,6 & 1,4 & 87,0 & 113,2 & 57,8 & 51,1 \\
\hline $\begin{array}{l}\text { JSC CB } \\
\text { "PRIVATBANK" }\end{array}$ & 178,3 & 166,0 & 93,1 & 62,7 & 11,5 & 18,3 & 248,7 & 177,4 & 71,3 \\
\hline JSC “Oschadbank” & 102,5 & 47,7 & 46,6 & 15,1 & 3,5 & 23,3 & 123,3 & 51,3 & 41,6 \\
\hline АБ "UKRGAZBANK" & 45,2 & 6,8 & 15,1 & 6,4 & 2,1 & 33,2 & 56,3 & 9,0 & 15,9 \\
\hline CB "Raiffeisen Bank" & 48,3 & 0,8 & 1,7 & 8,9 & 0,8 & 9,3 & 62,7 & 1,6 & 2,6 \\
\hline CB “OTP Bank" & 26,0 & 1,6 & 6,2 & 10,2 & 2,0 & 19,4 & 37,1 & 3,6 & 9,7 \\
\hline CB "UKRSIBBANK" & 16,1 & 0,1 & 0,8 & 6,8 & 1,4 & 20,4 & 36,9 & 1,5 & 4,1 \\
\hline $\begin{array}{l}\text { CB "Crédit } \\
\text { Agricole Bank" }\end{array}$ & 22,4 & 0,4 & 1,9 & 5,5 & 0,3 & 4,8 & 27,9 & 0,7 & 2,4 \\
\hline CB "ALFA-BANK" & 33,6 & 3,1 & 9,1 & 30,2 & 12,9 & 42,5 & 65,7 & 15,9 & 24,2 \\
\hline CB "SBERBANK" & 38,3 & 33,1 & 86,3 & 2,0 & 2,0 & 98,4 & 40,4 & 35,1 & 86,9 \\
\hline $\begin{array}{l}\text { PJSC } \\
\text { "PROMINVESTBANK" }\end{array}$ & 24,7 & 23,6 & 95,6 & 0,1 & 0,1 & 100,0 & 24,8 & 23,7 & 95,7 \\
\hline $\begin{array}{l}\text { CB "First Ukrainian } \\
\text { International Bank } \\
\text { (FUIB)"، }\end{array}$ & 30,8 & 2,7 & 8,7 & 18,2 & 1,4 & 7,7 & 49,2 & 4,1 & 8,3 \\
\hline CB "Universal Bank" & 2,8 & 0,1 & 3,0 & 22,9 & 2,9 & 12,8 & 25,9 & 3,0 & 11,6 \\
\hline CB "Pivdenny Bank" & 19,7 & 1,1 & 5,6 & 0,3 & 0,1 & 33,8 & 20,0 & 1,2 & 6,1 \\
\hline CB "TASCOMBANK" & 11,1 & 0,4 & 3,2 & 3,0 & 0,9 & 29,8 & 14,5 & 1,2 & 8,6 \\
\hline
\end{tabular}

Source: Official website of the NBU, www.bank.gov.ua.

Calculations show that the optimal size of the authorized capital of the National Development Bank should be at least $0.5 \%$ of the country's GDP, which is approximately 525 million euros. For comparison, today the authorized capital of systemically important state banks of Ukraine is 11 billion EUR in equivalent, including PrivatBank (7.6 billion EUR) [1]. In the case of successful privatization of state-owned banks, it is advisable to direct part of the funds to the formation of the authorized capital of a full-fledged development bank. At the same time, the functions of UkrEximBank should be supplemented with the tasks of export insurance, which requires institutional development in cooperation with the Export Credit Agency.

\section{CONCLUSIONS}

State-owned banks in our immediate partner countries have access to long-term borrowing from international financial institutions. There is a positive correlation between the growth rate of gross domestic product and the volume of assets and loans of stateowned banks. Banks with the participation of the state in capital are able to work efficiently. In Ukraine, on the basis of existing state-owned banks, it is advisable to create a national development bank with an appropriate business model and strategy. All four state-owned banks should not be put up for sale, as their current development strategy suggests. The key factor in the success of stateowned banks is the quality of corporate governance, 
independence and responsibility of management, the constructive influence of government agencies on the strategy of banks.

\section{REFERENCES}

[1] Lyubich, O.O. Bortnikov, G.P. Drobyazko, A.O. (2020), "Comparative analysis of state-owned banks' role in the economy of eastern Europe countries and Ukraine", Financial and credit activity: problems of theory and practice Published, vol. 1, no. 32, pp. 57-64, DOI: $10.18371 /$ fcaptp.v1i32.200286

[2] Ala Arman (2016), "A Risk-Aware Application Scheduling Model in Cloud Computing Scenarios", International Journal of Intelligent Systems and Applications, vol. 8, no. 10, pp. 11-20, DOI: $10.5815 /$ ijisa.2016.10.02

[3] Ahmed Hassan Mohammed Hassan, Arfan Ali Mohammed Qasem, Walaa Faisal Mohammed Abdalla and Omer H. Elhassan (2021), "Visualization \& Prediction of COVID-19 Future Outbreak by Using Machine Learning", International Journal of Information Technology and Computer Science, vol. 13, no. 3, pp. 16-32, DOI: $10.5815 /$ ijitcs.2021.03.02

[4] Joann Galopo Perez and Eugene S. Perez (2021), "Predicting Student Program Completion Using Naïve Bayes Classification Algorithm", International Journal of Modern Education and Computer Science, vol. 13, no. 3, pp. 57-67, DOI: 10.5815/ijmecs.2021.03.05

[5] Nor Hamizah Zulkifley, Shuzlina Abdul Rahman, Nor Hasbiah Ubaidullah and Ismail Ibrahim (2020), "House Price Prediction using a Machine Learning Model: A Survey of Literature", International Journal of Modern Education and
Computer Science, vol. 12, no. 6, pp. 46-54, DOI: 10.5815/ijmecs.2020.06.04

[6] Korystin, Oleksandr and Svyrydiuk, Nataliia (2021), "Activities of Illegal Weapons Criminal Component of Hybrid Threats", Proceedings of the International Conference on Economics, Law and Education Research (ELER 2021), vol. 170, 22 March, pp. 86-91, DOI: 10.2991/aebmr.k.210320.016

[7] Arzhevitin, S.M. Drobyazko, A.O. (2020), "Updating approaches to substantiation of Ukraine's anti-crisis monetary policy", Finance of Ukraine, no. 4 (293), pp. 7-26, DOI: $10.33763 /$ finukr2020.04.007

[8] Drobyazko, A. (2019), "Features of the monetary policy of Poland, Romania, Hungary, the Czech Republic: tools and mechanisms for influencing economic acceleration", Vydannya Tsentru Razumkova. Posylennya znachymosti monetarnoyi polityky $v$ krayinakh Tsentral'noyi $i$ Skhidnoyi Yevropy u postkryzovyy period $i$ rekomendatsiyi dlya Ukrayiny, Nauk. red. V.Yurchyshyn, Zapovit, Kyyiv, pp. 83-95.

[9] Tkachenko, Volodymyr Kwilinski, Aleksy Korystin, Oleksandr Svyrydiuk, Natalia and Tkachenko, Iryna (2019), “Assessment of information technologies influence on financial security of economy", Journal of security and sustainability issues, march, vol. 8 , no. 3 , pp. 375 385, DOI: 10.9770/jssi.2019.8.3(7)

[10] Drobyazko, A. (2020), “Asymetrychnyy vplyv hroshovykh potokiv mizh real'nym i bankivs'kym sektoramy na monetarne rehulyuvannya v konteksti natsional'noyi bezpeky", Finance of Ukraine, no. 11, pp. 56-75, DOI: $10.33763 /$ finukr2020.11.056 